\title{
Si ウエハの貫通電極形成技術
}

\author{
星 野 雅 孝* \\ *技術研究組合 超先端電子技術開発機構 電子 SI 技術研究部 筑波研究セン夕 \\ （干305-0047＼cjkstart茨城県つくば市千現 2-1-6 つくば研究支援センター内 C-B-5）
}

\section{Through Electrode in Si Wafer}

\begin{abstract}
Masataka HOSHINO*
*Tsukuba Research Center, Electronic System Integration Technology Research Department, Association of SuperAdvanced Electronic Technologies (ASET) (C-B-5, TCI, 2-1-6, Sengen, Tsukuba-shi, Ibaraki 305-0047)
\end{abstract}

Key Words : Electronic System Integration, Three-Dimensional Packaging, Through via, Wafer Thinning, Flip Chip Bonding, Under-Fill, Thermal Management

\section{1.はじめに}

貫通電極を利用した三次元積層 LSI の考えや研究の歴史は長 い。特許に関しては 1968 年の IBM の特許 ${ }^{1)}$ からはじまり, 多 数の特許が出願されている。研究プロジェクトとしても, 本プロ ジェクトの前に 1981 年より 10 年間, 通産省工業技術院から委 託を受けた財新機能素子研究開発協会によって「三次元回路素子 研究開発プロジェクト」の研究開発が行われた。このプロジェク 卜の目的は, 集積回路の二次元的集積が素子微細化技術の限界並 びに素子微細化にともなう動作阻害要因の発生により生ずるであ ろう限界を打破し, 積層高密度集積素子技術および積層大容量多 機能集積素子技術を確立するものであった。順次積層方式：SOI 構造をビームアニール SOI 結晶成長技術などで順次積層する方 式や, 張り合わせ方式：ハイブリッド的なアプローチとして張り 合わせ方式による三次元 IC などが研究された。このプロジェク トでは最終的に順次積層方式と張り合わせ方式との統合によって 4 層デバイスの試作評価を行いリングオシレータの動作確認を 行っている。

これらの研究開発で SOI 技術, 多層配線技術, 微細加工技術 など現代の半導体産業を支える多くの要素技術を確立し大きな成 果を上げたが, 三次元回路素子としては工法の工業化への難しさ があり, 現在に至るまで実用化されていない。実際には, トラン ジスタの微細化による進歩がすすみ, 三次元化するまでもなく, 所望の特性が得られてきたことが大きい。貫通電極を利用した三 次元積層 LSI の研究は現在でも研究は盛んに行われており 2) 4), 本プロジェクト ${ }^{5), 6)}$ も含め三次元積層 LSI の実用化への道を摸索 している。現在, パッケージ分野から異種の LSI チップを直接 積層してシステムを組み上げるパッケージが実用化している7),8)。 LSI 多層配線による信号遅延の面から, 貫通電極により LSI チップを三次元に積層してこの問題を回避するシミュレーション も盛んに行われている9),10)。

貫通電極により LSI チップを三次元に積層して超高性能デバ イスを作り上げることは LSI 技術者の夢であるが, 長年実用デ
バイスにはならなかった。

ASET では, 平成 11 年度から「超高密度電子システムインテ グレーション技術の研究開発」の一部として, 貫通電極により LSI チップを三次元に積層する技術開発を行っている。ASET では貫通電極形成プロセスが産業界にいち早く受け入れられるこ とを目指して, プロセス工程の構築には以下のことを考慮した。

1 ）現状の LSI 製造プロセス工場での使用が容易なこと。

a ）現存の量産対応装置をなるべく多く使えること。

b）前後の現状プロセスと接続性があること

2) 微細化に十分対処できること。

3 ) 将来的にベストのパフォーマンスが提供できること。

この観点から，我々は，LSI の Cu 配線プロセスをベースに構 築した。

現存デバイスメーカは $\mathrm{Cu}$ 配線の量産対応装置を多く所有して おり，前後の現状プロセスとは当然接続性があり，微細化に十分 対処できる。また $\mathrm{Cu}$ という低抵抗配線およびそれと共に開発さ れている低誘電体膜が利用でき将来的にベストのパフォーマンス が提供できる。

しかし，後に述べるが，組み上げた現状プロセスでは，まだ工 程数が非常に多い。実際に実用化させるためには，さらに簡便な 貫通電極プロセスの開発および貫通電極プロセスを現状の LSI 多層配線プロセス形成と同時に行える工程を多くして, トータル のプロセス工程数を極力減らせるかにかかっている。

本プロジェクトのバンプ接合の目標值は接合ピッチの先進性か らまた $10 \mathrm{~mm}$ 角ダイで周辺 2000 ピンの接合ができるように 20 $\mu \mathrm{m}$ ピッチ, $10 \mu \mathrm{m}$ 角と目標を設定し, 貫通電極サイズも, 20 $\mu \mathrm{m}$ ピッチ, $10 \mu \mathrm{m}$ 角を目標とした。ウエハ厚さは $\mathrm{Cu}$ 埋め込み の限界と現状での薄型化の実力から $50 \mu \mathrm{m}$ 厚を目標とした。

本報告では，採用したプロセス工程のプロセスフローの説明と その研究開発の状況を報告する。 


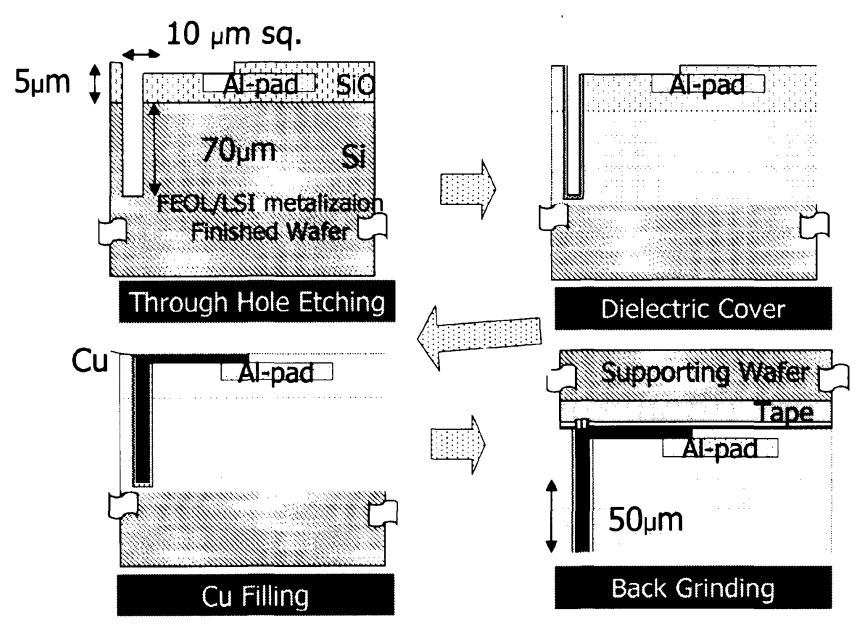

(a)

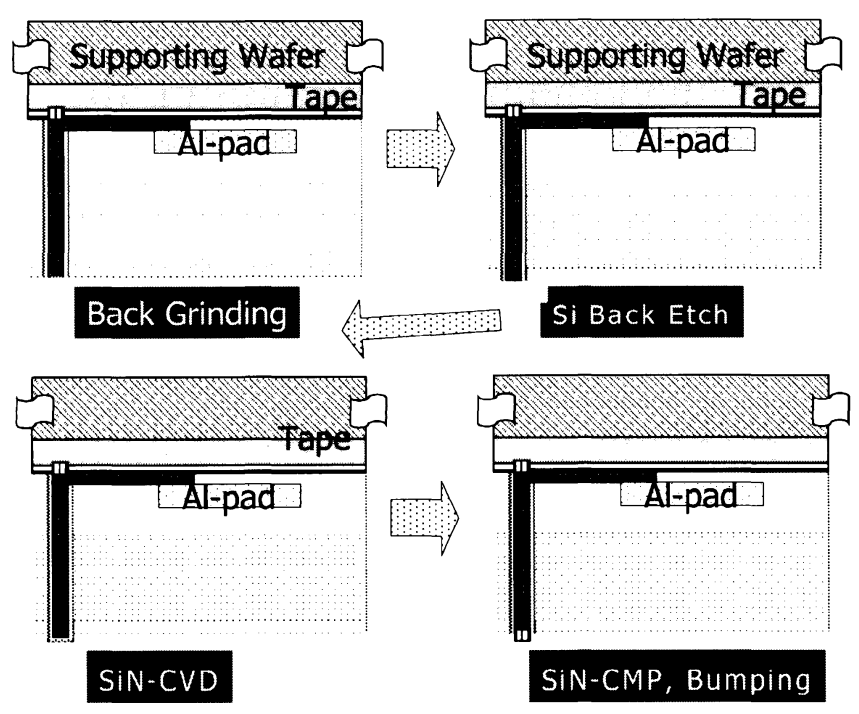

(b)

図 1 プロセスフロー

\section{2. 実験と結果}

\section{1 プロセスフロー}

プロセスフローを図 1 に示す。前述したように貫通電極のプロ セスは，装置が量産用として存在する物を基本に組み立てられて いる。表面工程では, 唯一, シリコン深堀エッチング装置が LSI プロセスにより使用されていない装置である。しかし，シリコン 深堀エッチング装置は MEMS(Micro electro Mechanical System)用にすでに実用化されている。産業への応用としては, 加 速度センサ(自動車のエアバック起動用センサ)やインクジェッ トプリンタヘッドの製造として多く用いられている。LSI 工場に 導入することにも抵抗は少ない。ASETでの貫通電極プロセス は LSI プロセスが終了したウエハを再加工して積層することを 前提に考えられている。

以下にプロセスフローの説明を記す。

(1) LSI プロセスが終了したウエハにシリコンエッチ時のマスク

と $\mathrm{Cu}$ 再配線となる溝を形成するための酸化膜を $3 \mu \mathrm{m}$ 程成膜 する。

(2)デバイスパッドと貫通電極を結線するために再配線用の溝エッ
チを行う。再配線は $\mathrm{Cu}$ ダマシン法により形成される。 $\mathrm{Si}$ 深 孔用マスクで露光し, Si エッチングを行う。

(3) $\mathrm{Si}$ 基板と貫通電極とを絶縁する。デバイスパッド上の絶縁膜 を RIE(Reactive Ion Etching)でエッチングする。

(4) CVD (Chemical Vapor Depositino) - $\mathrm{Cu} / \mathrm{TiN}$ を成膜し, 電 解めっきで $\mathrm{Cu}$ を埋め込む。

(5)上面の $\mathrm{Cu}$ を $\mathrm{CMP}$ (Chemical Mechanical Polishing)により 除去する。

(6)カバー膜を付け, バンプ窓を開口し, マイクロバンプを形成す る。

(7)支持体 $(725 \mu \mathrm{m}$ 厚のガラス板)を貼付け，裏面を研削する。 (8)裏面 $\mathrm{Si}$ をドライエッチして, $\mathrm{Cu}$ プラグを飛び出させる。

(9)裏面に CVD- $\mathrm{SiO} / \mathrm{SiN}$ を成膜する。

(10) $\mathrm{SiN}$ をMPし， Cu プラグの頭出しを行う。

(11)マイクロバンプを形成する。

(12)支持体をはく離する。

特に工程の(7)一(10は, 今までの LSI プロセスとは異なるプロ セスである。工程(8)以降で, $50 \mu \mathrm{m}$ 厚さのウエハのままプロセス ができるようになれば, 支持体の貼付け, はがしの工程は不要に なりプロセスが簡略化される。現在の市販装置では, $50 \mu \mathrm{m}$ 厚さ のウエハのままハンドリングおよびプロセスが不可能のため ASET では支持体プロセスを採用した。支持体をウエハに貼り つけるにはテープにより行っているが，テープの耐熱性が $120^{\circ} \mathrm{C}$ 程度なので, ドライエッチングと CVD-SiO/SiN の工程の低温 化が開発の焦点となる。量産用装置として存在しないものは, 支 持体貼付け $(725 \mu \mathrm{m}$ 厚のガラス板) と支持体はく離である。 50 $\mu \mathrm{m}$ 程度の薄ウ工八は近年開発が進み, 産業で用いられて来てい る。現状では装置がないが, 近い将来, 薄ウエハヘプロセスを行 うための技術が確立され，量産装置が販売されると考えられる。

貫通電極ウエハによるプロセスは以下に示すように工程(8)まで 開発されている。個別プロセスは, (9)の低温 $\mathrm{SiN}$ 成膜, (12)の支 持体はく離も確認した。今後, 裏面絶縁膜形成後の工程(10), (11) の開発を目指す。

\section{2 シリコン深堀エッチング}

貫通電極用のシリコン深孔エッチングは Reactive Ion Etching（RIE）により行った。現状のレーザ技術での貫通孔形成は， $10 \mu \mathrm{m}$ 径, $70 \mu \mathrm{m}$ と小さく深い孔を効率良く形成することが難し く, ASET では RIEで試作を行っている。孔サイズとエッチン グ深さの関係は, 孔径が大きくなるとエッチングレートが速くな るという通常のビアホールエッチと同じ傾向を示す。裏面工程お よび $\mathrm{Cu}$ 埋め込みを考えると孔径は単一の径にする必要がある。 本プロジェクトの目標である $10 \mu \mathrm{m}$ 角の $70 \mu \mathrm{m}$ 深さが達成でき ている。図 2 にその様子を示す。また側壁は非常に滑らかになっ ており, 側壁絶緑膜を成膜し, Si 貫通電極の絶縁性を良好に保 つことができる。 RIEによるエッチングでは $\mathrm{SiO}$ マスク下の $\mathrm{Si}$ がエッチングされて酸化膜マスクがオーバハングするという問題 点がある。現状では $0.5 \mu \mathrm{m}$ である。このために後の工程での $\mathrm{Cu}$ 埋め込みにおいて， $\mathrm{Cu}$ 中にボイドができてしまうという問 題点が残る。今後, 再エッチングにより庇を無くし, 埋め込み状 態を向上することを目指す。

\section{3 側壁絶緣膜形成}

Si と貫通電極を絶縁するために Si 孔の側壁に絶緑膜を形成す 


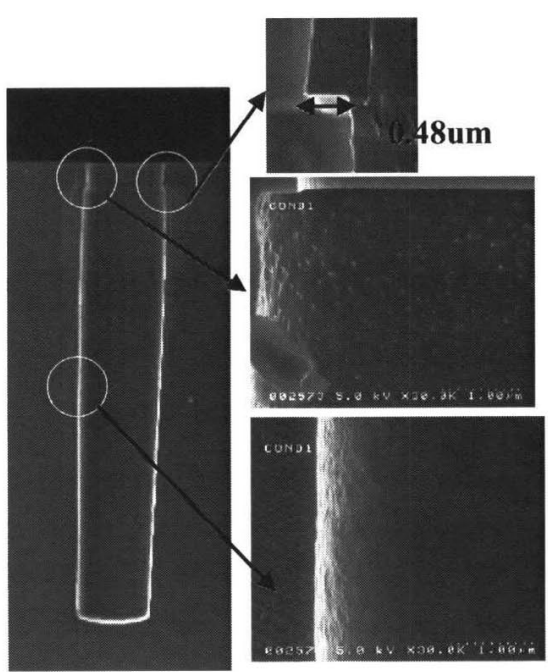

図 2 ディープ Deep Si-viaエッチング

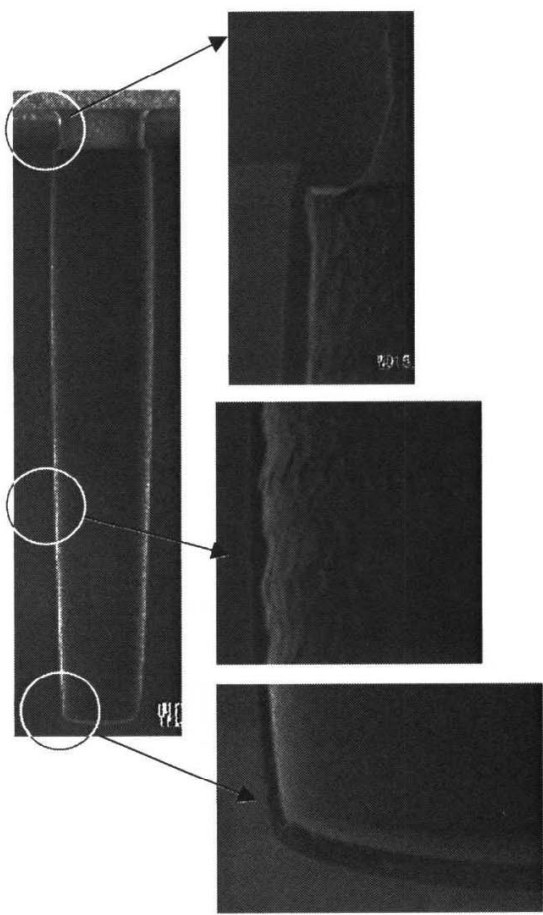

図3 プラズマ CVD TEOS- $\mathrm{SiO}_{2}$ 膜

る。カソードカップリングのプラズマTEOS-CVD装置を利用 して行った。図了にSiビアに成膜した様子を示す。酸化膜仳の 下部やビアボトムまでカバレージよく成膜されている。ステップ カバレージは 8-16\%程度である。成膜圧力を変化させても劇 的に改善はされない。

プロセスパラメータ (ガス流量, 圧力, RF パワー) と成膜特性 (貫通孔でのカバレッジ，デポレート)との関係を調べた。開口 $10 \mu \mathrm{m}$ 深さ $60 \sim 65 \mu \mathrm{m}$ の孔の内面に, 孔の開口部から底部まで 少なくとも $100 \mathrm{~nm}$ 以上絶緑膜を成膜できるよう最適化を図った。 デポレートは主にTEOS流量に依存しており，流量を増やすと ほぼリニアにレートが増える。圧力，RF-Powerについては, 変動幅が少なく, 顕著な依存性は見出せなかった。膜の残留応力 に対しては顕著な依存性を見出せなかった。カバレッジは RFパ

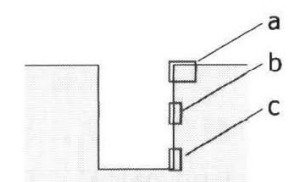

Si

$(\mathrm{TiN}=10 \mathrm{~nm}, \mathrm{Cu}=50 \mathrm{~nm})$

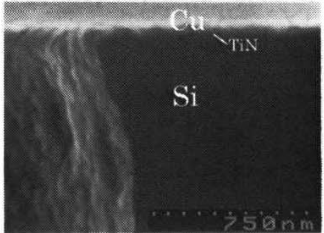

(a)

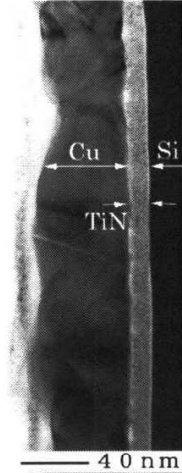

(b)

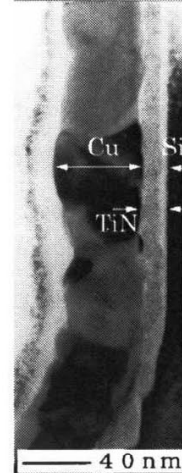

(c) (a)
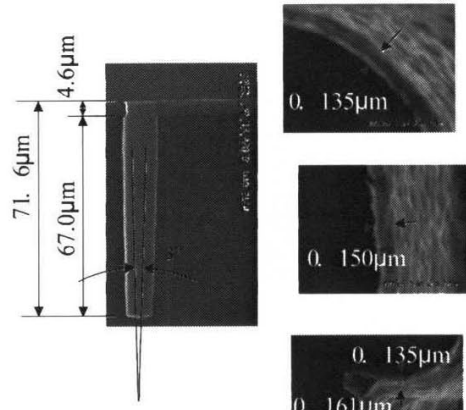

Hole Top
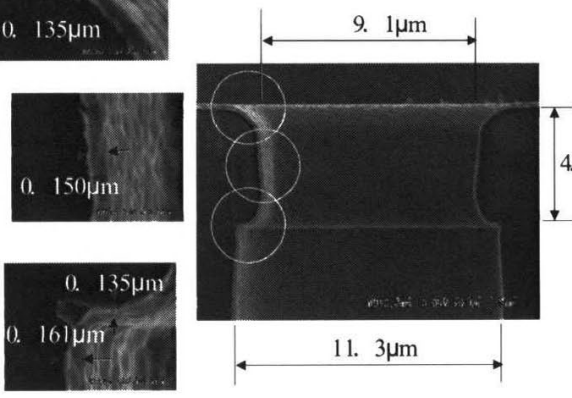

(b)
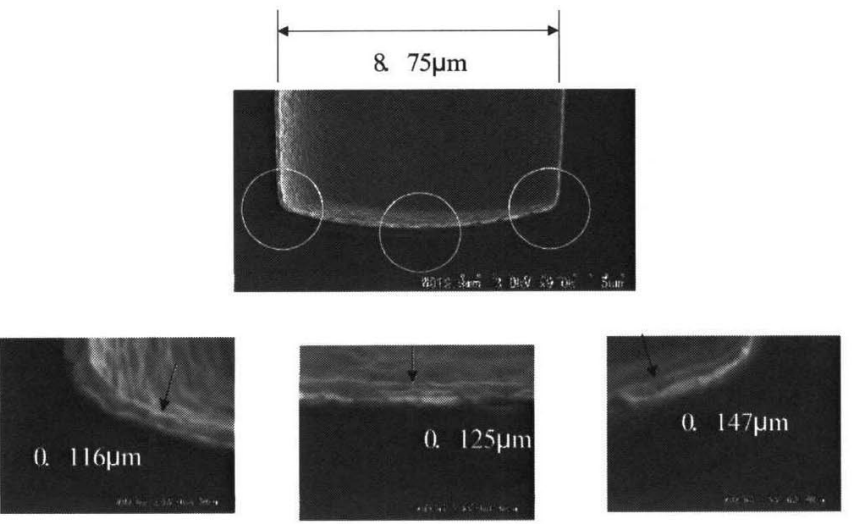

(c)

図 $4 \mathrm{Cu} / \mathrm{TiN}$ カバレージ結果

ワーを増やす (=Bias を増やす) と向上する。条件検討の結果， 孔底部で十分な膜厚が確保できる範囲で成膜速度を装置が安定動 作する範囲で上限まで上げた成膜条件を採用することとした。本 条件を用いて $\phi 8$ ”ウエハに成膜した場合では, 側壁のカバレッ ジは 15\%程度であった。

\section{2. $4 \mathrm{Cu}$ 埋め込み}

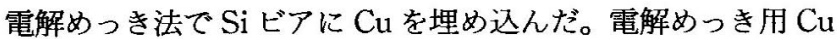
のバリヤメタル/シード層の形成には CVD法を用いた。CVDで は，側壁へおよびマスク庇下へのカバレージが良好である。図 4 にそのカバレージを示す。現状の構造では，酸化膜マスクがオー バーハングしており, PVD(Physical Vapor Deposition)によ る成膜は行えない。

電解めっきによる銅めっきの様子を図 5 に示す。貫通電極内に 
は若干ボイドが発生している。現状では，高アスペクトでビアが 垂直に立っており，酸化膜マスクの庇があるため，Cuにはボイ ドが残る。ボイド消失は再エッチングにより庇をなくすことと $\mathrm{Cu}$ めっきの改善により, 解消されつつある。Cu-CMPにより, 上面の $\mathrm{Cu}$ を除去する。 $\mathrm{Cu}$ めっき厚さと Cu-CMP の面内均一性 を向上することにより，残りなく $\mathrm{Cu}$ を除去できた。

\section{5 薄型ウエハハンドリングとウエハ薄型化}

ウエハ薄型化工程はウエハ裏面に Cu プラグを露出させること

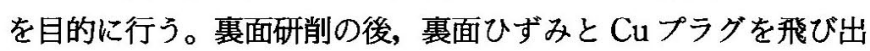
させるために，Si エッチを行う。図６に支持体をウエハに貼り つけた構造と研削後の露出した $\mathrm{Cu}$ の状況を示す ${ }^{11}$ 。ウエハは\# 600 および\# 2000 により研削を行った。Si-Cu を同時に研削する と $\mathrm{Si} へ$ へ Cuのだれが観察される。これは，\#2000砥石により かなり少なくすることができる。また，砥石にビトリファイドの

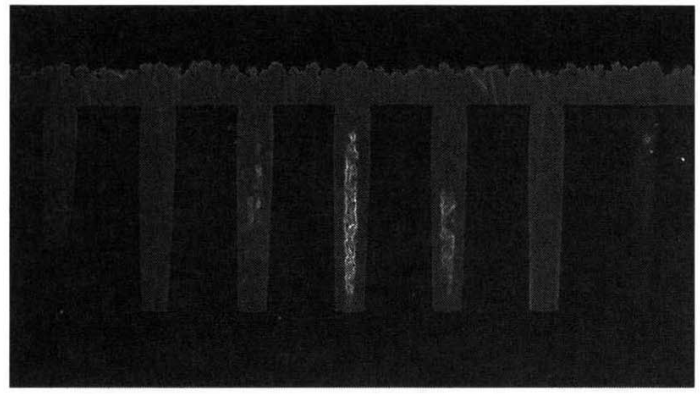

図 $5 \mathrm{Cu}$ めき結果

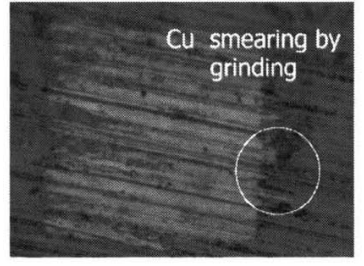

\#600

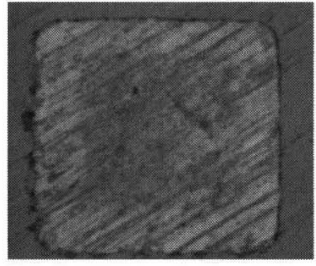

\#2000

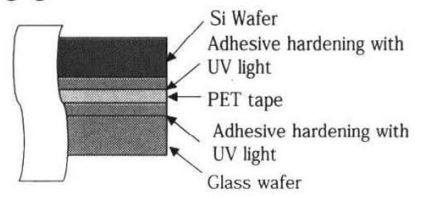

図6 $\mathrm{Cu}$ 電極のグラインディングとエッチング結果
結合材を用いることにより，Cuによる目詰まりを回避できた。 支持体とシリコンウエハを貼り合わせているテープと接着剤は $120^{\circ} \mathrm{C}$ 以上の高温で劣化するため, 低温のドライエッチング方法 を用いた。この方法により，バックグラインディングの後, $\mathrm{SF}_{6}$ ガスを用いて RIE法により $5 \mu \mathrm{m}$ ドライエッチングを行った。 $5 \mu \mathrm{m}$ エッチングした後ではダメージを完全に取り去ることがで きた。そのことをX線卜ポグラフィにより確認した。またドラ イエッチング後のストレスが消失することを Raman 分光法によ り観察した。図7にドライエッチング後の外観写真を示す。テー プのはく離なく,ドライエッチングが行われ, 裏面も白濁なくド ライエッチングが可能である。図 8 に裏面の $\mathrm{Cu}$ プラグを飛び出 させた写真とその断面写真を示す。良好な $\mathrm{Cu}$ プラグが形成でき ている。

\section{6 衰面絶緑膜形成}

裏面絶縁膜は，襄面ドライエッチングで露出した Si と貫通電 極を完全に絶縁するために必要となる。裏面電極露出工程数をな るべく少なくするために CMPにより Cu プラグを露出させる方 式を採用した。そのため, LSI 配線工程の多層配線で CMP が行 われている $\mathrm{SiO} / \mathrm{SiN}$ 構造を採用した。 $\mathrm{SiN}$ はドライエッチング で露出している Cu と密着性が良く $\mathrm{Cu}$ の拡散が押さえられるの で用いた。まず, SiN 単層の成膜温度データから取得した。支 持体を接着しているテープおよび接着材が $120^{\circ} \mathrm{C}$ 以上の高温で少 化するため，低温で成膜する必要がある。すでに SiN 膜の低温 成膜の形成装置は，CVD，スパッ夕法で各種市販されており， 樹脂・プラスティックへのコーティングや化合物半導体への成膜 に使われている。P-TEOSと同じ方式のカソードカップリング 方式の平行平板プラズマ CVD装置を用いて，P-SiN 膜を形成

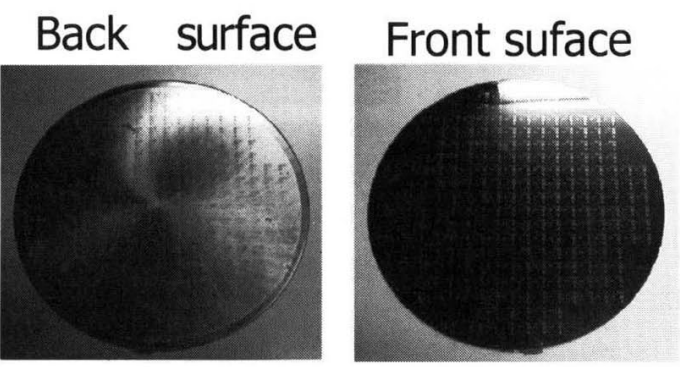

図 7 ドライエッチング後の $\mathrm{Si}$ 表面

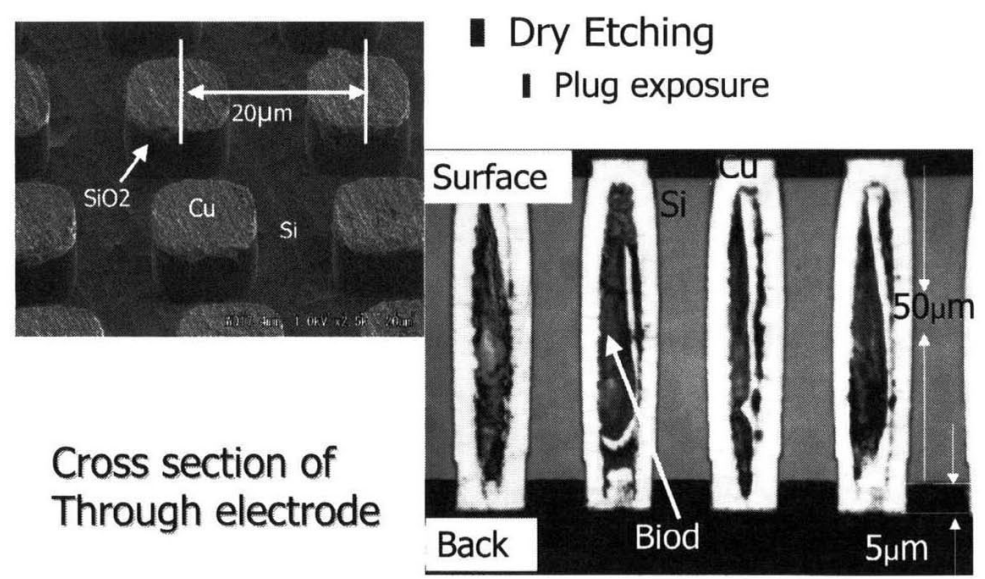

図 8 ドライエッチング結果 
した。これは既にポリカーボネートへの成膜が報告されている ${ }^{12)}$ 。 $50 \mu \mathrm{m}$ 厚さのガラス支持体付きの Si チップ上に CVD 法により， $\mathrm{SiN}$ を $1.75 \mu \mathrm{m}$ 成膜した。この条件では，テープの変質がない ことを確認した。成膜された $\mathrm{SiN}$ 膜の剥れも無かった。

\section{3.まとめ}

貫通電極に関して, $10 \mu \mathrm{m}$ 角, $70 \mu \mathrm{m}$ 深のシリコン孔の形成, 側壁絶縁膜形成， $\mathrm{Cu}$ 埋め込みおよび裏面研削，裏面 $\mathrm{Si}$ エッチ ングおよび裏面絶緑膜形成の実験結果を示した。Cu埋め込みに 関して現状では高アスペクトでビアが垂直に立っており酸化膜マ スクの庇があるため, Cuにはボイドが残る。ボイド消失は庇除 去と $\mathrm{Cu}$ めつきの改善により解消されつつある。ウエハ薄型化は, 研削による $\mathrm{Cu}$ プラグだし条件およびドライエッチングの条件を 見出した。裏面絶縁膜の形成は支持体付きにて $\mathrm{SiN}$ の成膜条件 を見出した。

電極形成技術は, LSI 多層配線の技術を使用したため, 従来の 装置で比較的容易にプロセスを立ち上げることができた。裏面工 程とくにハンドリングに関しては，新しい技術が必要となる。 ASETでは裏面工程を新たに開発した。なるべく市販装置もし くは市販可能レベルの装置を用いてプロセスを構築したが, 薄型 ウエハのハンドリング(支持体脱着) は従来の装置が存在しない。 この薄型ウエハのハンドリングの技術が, 今後の上記プロセスが 実用化できるかのキープロセスである。ASETでは，薄型ウエ ハのハンドリング技術を引き続き開発して行く。

\section{謝辞}

この研究開発は NEDO (New Energy Development Industry Organization)の委託により,「超高密度電子システムインテグ
レーション $(\mathrm{SI})$ 技術の研究開発」の一部として行われた。

(2001-5-30 受理)

\section{文献}

1) K. Stuby and F. Wappingers, US Patent 3, 648, 131 (November 1969)

2) K. W. Lee, T. Nakamura, K. Sakuma, K. T. Park, H. Shimazutsu, N. Miyakawa, K. Y. Kim, H. Kurino and M. Koyanagi; Jpn. J. Appl. Phys., 39, (2000), 2473-2477

3 ) K. Sasaki, M. Matsuo, N. Hayasaka, K. Okumura; International Conference on Electronics Packaging April 18, 2001 Tokyo Japan

4 ) P. Ramm, D. Bonfert, H. Gieser, F. Iberl, A. Klumpp, R. Wieland, J. Hauge and A. Kux; Interanational Interconnect Technology Conference June 5, 2000 Burlingame CA.

5 ) M. Bonkhara; "Japan Activities in 1999 Electronic SystemIntegration Technology", 6 th Annual KGD Industrial Workshop, Sep. 1999, Napa Valley

6 ) K. Takahashi et al.; Jpn.J. Appl. Phys., 40, No. 4 B 3032 (2001)

7 ）藤田他; シャープ技報, p. 58, August（1998）

8 ）持田他; 日経エレクトロニクス, p. 198, No. 782（2000）

9 ) Y. Deng and W. Maly; p. $326,7^{\text {th }}$ Annual KGD Packaging \& Test Workshop September 2000, Napa, CA.

10) J. W. Joyner et al.; p. 126, Interanational Interconnect Technology Conference June, 2000 Burlingame CA.

11）春原他; 第 15 回エレクトロ実装学術講演大会講演論文集 p. 67 (2001)

12) (侏サムコインターナショナル研究所開発室, SAMCO Technical-Report $6\lceil\mathrm{SiH}$ 4-NH 3 混合ガスによるシリコン窒化 の高速堆積法」 